\title{
QUALITY OF MILK FATTY ACID DURING LATE LACTATION IN DAIRY GOAT FED ON PUFA-DIET SUPPLEMENTED WITH YEAST AND Curcuma xanthorrhiza Roxb
}

\author{
E. Sulistyowati ${ }^{1,2}$, A. Sudarman ${ }^{1}$, K.G. Wiryawan ${ }^{1}$ and T. Toharmat ${ }^{1}$ \\ ${ }^{1}$ Faculty of Animal Science, Bogor Agricultural University, \\ Jl. Agatis Bogor, Indonesia 16680 - Indonesia \\ ${ }^{2}$ Permanent Address: Faculty of Agriculture, University of Bengkulu, \\ Jl. WR. Supratman Bengkulu 38371 - Indonesia \\ CorrespondingE--mail:ensulistyowati@yahoo.com
}

Received October 13, 2013; Accepted November 29, 2013

\begin{abstract}
ABSTRAK
Ragi dan kurkumin dari $C$. xanthorrhiza Roxb (temulawak) dapat ditambahkan ke dalam konsentrat yang mengandung asam lemak tak jenuh (polyunsaturated fatty acid, PUFA) untuk memperbaiki kandungan asam lemak susu pada kambing perah. Terdapat lima perlakuan (PD0: PUFAdiet tanpa aditif; PDA: PUFA- diet dengan 3 tablet Asifit; PDY: PUFA- diet dengan $5 \mathrm{~g}$ ragi; PDC: PUFA- diet dengan $20 \mathrm{~g}$ tepung curcuma; dan PDM: PUFA- diet dengan campuran $5 \mathrm{~g}$ ragi dan $20 \mathrm{~g}$ tepung curcuma) diaplikasikan pada 20 ekor kambing perah pada fase laktasi akhir (4.6 \pm 0.55 bulan laktasi) menggunakan randomized complete block design. Hasil menunjukkan konsistensi pada PUFAdiet dengan $5 \mathrm{~g}$ ragi dan $20 \mathrm{~g}$ curcuma mengandung konsentrasi yang tinggi pada total fatty acid, MCFA, LCFA, dan PUFA. Kualitas asam lemak susu pada kambing perah dengan diet ini mengandung beberapa asam lemak dengan level yang tinggi, yaitu LCFA dan MUFA; namun, rendah untuk SCFA, n6/n3, dan atherogenicity index. Kualitas ini dinilai optimal dalam memproduksi susu yang sehat. Oleh karena itu, PUFA- diet dengan $5 \mathrm{~g}$ ragi dan $20 \mathrm{~g}$ curcuma merupakan pilihan yang tepat untuk diaplikasikan pada kambing perah.
\end{abstract}

Kata Kunci: asam lemak susu kambing, Curcuma, PUFA-diet, ragi

\begin{abstract}
Yeast and curcumin of C. xanthorrhiza Roxb could be added into concentrate containing polyunsaturated fatty acid (PUFA) to improve milk fatty acid quality of dairy goat. There were five treatments (PD0: PUFA- diet with no additive; PDA: PUFA- diet with 3 Asifit tablets; PDY: PUFA- diet with $5 \mathrm{~g}$ yeast; PDC: PUFA- diet with $20 \mathrm{~g}$ curcuma powder; and PDM: PUFA- diet with a mixture of 5 $\mathrm{g}$ yeast and $20 \mathrm{~g}$ curcuma powder) applied onto 20 dairy goats during late lactation $(4.6 \pm 0.55$ months of lactation). The treatments were allocated according to a completely completely randomized block design. Results demonstrated that diet containing PUFA supplemented with $5 \mathrm{~g}$ yeast and $20 \mathrm{~g}$ curcuma were high in total fatty acid, medium chain fatty acid (MCFA), and long chain fatty acid (LCFA). Milk of goats with this treatment showed high in mono unsaturated fatty acid (MUFA) and MUFA; while it was low in short chain fatty acid (SCFA), n6/n3 ratio, and atherogenicity index. These qualities were optimally considered good in terms of healthier product. Therefore, the PUFA- diet with $5 \mathrm{~g}$ yeast and $20 \mathrm{~g}$ curcuma was a reasonable choice to be applied for dairy goat.

Keywords: fatty acid, goat milk, curcuma, PUFA-diet, yeast
\end{abstract}

\section{INTRODUCTION}

Milk fatty acid has been an increasing concern for healthy reason. Different from milk of cow that contains higher long chain fatty acid
(LCFA); milk dairy goat is higher in short chain fatty acid (SCFA), and long chain fatty acid (MCFA) (Bouattour et al., 2008).

There have been some nutrients efforts to modify this fatty acid content, such as providing 
diet containing polyunsaturated fatty acid (PUFA) supplemented with yeast and Curcuma xanthorrhiza Roxb.

Several research results, such as flaxseed containing concentrate, treated or untreated with formaldehyde, showed moderate amount of C18:1 and high in C18:3. Whereas, in sun flower containing concentrate, both treated and untreated, C18:2 was found being the highest (Petit, 2003). This suggested that formaldehyde was not effective enough to protect PUFA against ruminal biohydrogenation. The PUFA supplementation (such as extruded soybean) in concentrate is incompletely biohydrogenised later in the bio system of ruminants which eventually affects fatty acid in milk, decreased SCFA and LCFA (Whitlock et al., 2002; Schmidely et al., 2005); also, addition of flaxseed products reduced n6/n3 in milk of dairy cow (Cortes et al., 2010). Feeding concentrate containing yeast and curcuma with different fatty acid sources (palm oil and roasted ground corn) showed optimal levels in PUFA, ratio of PUFA/saturated (P/S), and $\mathrm{n} 6 / \mathrm{n} 3$ designated for dairy cows (Sulistyowati et al., 2010).

Yeast supplementation was reported to affect fatty acid content in milk. Addition of $50 \mathrm{~g} / \mathrm{d}$ RumiSacc (containing 33.01\% saturated fatty acid-SFA, $26.42 \%$ PUFA, and $66.99 \%$ unsaturated fatty acid- UFA) did not affect the 18:3 (n-6), but did increase 18:3 (n-3) in milk of dairy cow (Yalçın et al., 2011).

Curcuma xanthorrhiza Roxb, a medicinal herb, contains bioactives of curcuminoids (curcumin, demethoxycurcumin, and bisdemethoxycurcumin). It has several biological activities, such as anti-inflammatory, antioxidant, and antimicrobial (Jayaprakasha et al., 2002), antifungal and antibiofilm (Rukayadi et al., 2008), also hypocholeretic. Liquid extract of $C$. xanthorrhiza Roxb in Tabut block was able to decrease fat content in milk of lactating Bali cow (Sulistyowati et al., 2001). Sinaga et al. (2011) found that curcumin $(160 \mathrm{ppm})$ in $C$. domestica did not affect HDL level in pig. Other herbal source, tea catechin inclusion was reported to decrease markedly in low-density lipoprotein cholesterol and triglyceride in blood of goat (Zhong et al., 2011).

Based on these data, an experiment has been conducted to investigate the effects of different additives, yeast, C. xanthorrhiza Roxb, and their combination added in concentrate containing PUFA sources (roasted ground corn, roasted soybean meal, and corn oil) on milk fatty acid in milk of dairy goat.

\section{MATERIALS AND METHODS}

\section{Preparation of Yeast, Curcuma, and PUFA- Diet}

Yeast additive was prepared from several ingredients based on a modification of the procedure of Pusbangtepa (1981), containing 3.6 $10^{7} \mathrm{cfu} / \mathrm{g}$. Curcuma powder was made of fresh $C$. xanthorrhiza Roxb tuber that was sliced, sun dried, oven dried, grounded, and refined. It contained curcumin $(0.8 \%)$ and tannin $(1.58 \%)$.

Diet containing PUFA - concentrate from the previous experiment, as part of three consecutive experiments was then combined with soybean byproduct used to be provided on the farm. The ground corn was half roasted, while the soy bean meal was all roasted in $80^{\circ} \mathrm{C}$ until turned light brown. The PUFA sources contained of $50.35 \%$, $34.69 \%$, and $46.46 \%$ out of total \% FAME (fatty acid methyl esters), for roasted soy bean meal, roasted ground corn, and corn oil, respectively. Cassava meal was prepared from the fresh tubers that was sliced, sun dried, then grinded as powder. Soybean by product was in the form of the skin of soybean after an extrusion from boiling it, made in some small scale tofu industries.

\section{Experimental Diets}

The PUFA- diet (PD) was formulated for 30 $\mathrm{kg}$ lactating dairy goat with $1 \mathrm{~kg}$ of milk production (NRC, 1981). The formula and nutrient contents of each treatment are presented in Table 1.

There were five treatments (PD0: PUFAdiet with no additive, as negative control; PDA is PUFA with 3 Asifit tablets, as positive control; PDY -PUFA with 5 g yeast; PDC - PUFA with 20 $\mathrm{g}$ curcuma powder; and PDM -PUFA with a mixture of $5 \mathrm{~g}$ yeast and $20 \mathrm{~g}$ curcuma powder). These diets were applied in 20 late lactation dairy goats. The goats were Ettawa crossed breed, in late lactation ( $4.6 \pm 0.55$ months), with body weight of $46 \pm 5.34 \mathrm{~kg}$, hand milked twice and recorded (at 06.00 and 03.00) in each individual stall. Results of average milk productions in post treatment were 105, 572, 526, 90, and $324 \mathrm{~g} / \mathrm{d}$ for PD0, PDA, PDY, PDC, and PDM, respectively.

ASIFIT, a tablet of feed supplement for a woman in lactation, contains of $114 \mathrm{mg}$ Sauropus androgynus, $20 \mu \mathrm{g}$ vitamin B12, $15 \mathrm{mg}$ vitamin $\mathrm{B} 6,2.5 \mathrm{mg}$ vitamin $\mathrm{B} 2$, and $10 \mathrm{mg}$ vitamin $\mathrm{B} 1$ 
Table 1. Ingredients and Nutrient Composition of PUFA-diet Containing Asifit, Yeast and $C$. xanthorrhiza Roxb for Dairy Goat

\begin{tabular}{|c|c|c|c|c|c|c|}
\hline Ingredients (\%) & PD0 & PDA & PDY & PDC & PDM & KG \\
\hline \multicolumn{7}{|l|}{ Feedstuff Composition: } \\
\hline Rice bran & 18.42 & 18.42 & 18.42 & 18.42 & 18.42 & - \\
\hline Ground corn & 15.79 & 15.79 & 15.79 & 15.79 & 15.79 & - \\
\hline Soy bean meal & 7.89 & 7.89 & 7.89 & 7.89 & 7.89 & - \\
\hline Cassava meal & 7.89 & 7.89 & 7.89 & 7.89 & 7.89 & - \\
\hline Soy bean by-product & 27.49 & 27.49 & 27.49 & 27.49 & 27.49 & - \\
\hline Corn oil & 2.11 & 2.11 & 2.11 & 2.11 & 2.11 & - \\
\hline Mineral & 0.53 & 0.53 & 0.53 & 0.53 & 0.53 & - \\
\hline King grass (KG) & 19.88 & 19.88 & 19.88 & 19.88 & 19.88 & - \\
\hline Asifit & - & 0.22 & - & - & - & - \\
\hline Yeast & - & - & 0.50 & - & 0.50 & \\
\hline Curcuma powder & - & - & - & 2.00 & 2.00 & \\
\hline \multicolumn{7}{|c|}{ Nutrients Contents (DM basis): } \\
\hline Drymatter $(\%)$ & 94.13 & 94.13 & 93.96 & 93.72 & 94.06 & 92.24 \\
\hline $\operatorname{Ash}(\%)$ & 8.48 & 8.48 & 7.96 & 7.82 & 8.21 & 11.65 \\
\hline Crude protein ( \%) & 15.27 & 15.27 & 14.11 & 15.33 & 15.04 & 13.42 \\
\hline Ether extract (\%) & 7.66 & 7.66 & 8.14 & 7.96 & 8.77 & 3.22 \\
\hline Crude fiber (\%) & 13.30 & 13.30 & 14.57 & 18.60 & 14.51 & 31.32 \\
\hline $\operatorname{NFE}(\%)$ & 49.12 & 49.12 & 49.18 & 44.0 & 47.60 & 32.64 \\
\hline $\operatorname{NDF}(\%)$ & 70.44 & 70.44 & 87.69 & 84.51 & 78.17 & 85.77 \\
\hline $\operatorname{ADF}(\%)$ & 29.07 & 29.07 & 29.54 & 48.18 & 29.35 & 78.99 \\
\hline Gross energy(Mcal/kg) & 3.84 & 3.84 & 3.86 & 3.83 & 3.90 & 3.71 \\
\hline $\mathrm{Ca}(\%)$ & 0.61 & 0.61 & 1.20 & 1.02 & 0.84 & 0.70 \\
\hline $\mathrm{P}(\%)$ & 0.47 & 0.47 & 0.53 & 0.57 & 0.29 & 0.13 \\
\hline $\mathrm{Ca} / \mathrm{P}$ & 1.30 & 1.30 & 2.26 & 1.79 & 2.90 & 0.64 \\
\hline Tannin $(\%)$ & 0.487 & 0.487 & 0.492 & 0.491 & 0.491 & - \\
\hline Curcumin $(\%)$ & - & - & - & 0.13 & 0.11 & - \\
\hline S. cereviseae $\left(10^{-6} \mathrm{cfu} / \mathrm{g}\right)$ & 1.6 & 1.6 & 7.3 & 1.2 & 4 & - \\
\hline
\end{tabular}

PUFA- concentrate and soybean by- product without supplements designated as (PD0), added with 3 tablets/dairy goat of ASIFIT (PDA), $0.5 \%$ or $5 \mathrm{~g}$ yeast (PDY), $2 \%$ or $20 \mathrm{~g}$ curcuma powder (PDC), mix of $5 \mathrm{~g}$ yeast and $20 \mathrm{~g}$ curcuma powder (PDM). $\mathrm{KG}$ is king grass.

(produced commercially by Kimia Farma, Indonesia). It was given 3 tablets orally in the morning after milking. King grass or Pennisetum purpureum was provided around $19-20 \%$ to the overall diet in each treatment.

Nutrient of dry matter (DM), organic matter
$(\mathrm{OM})$, crude protein $(\mathrm{CP})$, crude fiber $(\mathrm{CF})$, and ether extract (EE) were determined according to AOAC (1990). The content of NDF and ADF were analyzed using the method of Van Soest (199). Minerals of Ca was analyzed using Atomic Absorbance Spectrophotometer (AAS) AA7000 
Shimadzu Co. Serial no A 306647-00345 and measured at $\lambda 422.7 \mathrm{~nm}$; $\mathrm{P}$ was analyzed using wet ashing method and quantified using spectrophotometer UV-200 RS UV VIS LW Scientific and measured at $\lambda=660 \mathrm{~nm}$.

Bioactive of curcumin was determined using maceration method with the final product of crystal with orange- brown color as curcuminoid, in which curcumin was part of it (Sutrisno et al., 2008). Tannin was analyzed using polyphenol redox method then detected using Spectrophotometer (at $\lambda 725 \mathrm{~nm}$ ).

\section{Sample Collection, Data and Statistical Analysis}

Sampling and data recording were based on the length of the research that was divided into 14 days for adaptation, 21 days for treatment, and 21 days for post treatment. The application of the diets was in $5 \times 4$ Randomized Complete Block arrangement, then data were tabulated and statistically analyzed in Anova, any differences were detected using Duncan's multiple range test according to Lentner and Bishop (1986).

Each of the 20 goats was kept individually, provided with feed twice daily of $0.5 \mathrm{~kg}$ PUFAconcentrate and $1 \mathrm{~kg}$ of fresh soybean by-product at $06.00 \mathrm{am}$ and $03.00 \mathrm{pm}$. Forage was given 2 $\mathrm{kg} /$ goat on afternoon feeding. Refusals of concentrate and forage were weighed in the next morning. Water was given during afternoon feedings daily. The 3 tablets of Asifit were given orally to the respected goats in the morning feedings; whereas yeast, curcuma, or combination of both were put as topping on the mixture of PUFA- concentrate. As the Asifit tablets were given orally, therefore the of this diet was using the same result as the control diet (PD0).

Milk yield was recorded daily before, during, and post treatment. Sampling of individual milk was collected from two consecutive milkings of the afternoon and the next morning of the last day of collection time during the treatment period.

\section{PUFA Analysis, Calculation and Environment}

Milk fatty acids were analyzed after extraction of milk fat samples and methylation yielding fatty acid metil ester (FAME). The same procedures were also applied for diets and feces. Separation and quantification of the FAME were conducted by using gas chromatography (GCFID, 2010 Plus, Shimadzu, Japan).

Fatty acids and their ratios were calculated as follows: total SCFA $(\mathrm{C}<10)$, MCFA (C12-
C16), LCFA (C>C16), MUFA ( $\mathrm{C}$ with one double bond), PUFA, SFA and UFA, ratio of PUFA/saturated fat (P/S), ratio of n6/n3: (linoleic acid + arachidonic acid)/linolenic acid (Schmidely et al., 2005), and Atherogenicity index: (C12 + $4 \mathrm{C} 14+\mathrm{C} 16$ )/total unsaturated fat (Ulbricht and Southgate, 1991).

Temperature and humidity around Cordero farm in the upper land of Bogor, West Java, were recorded at 6 am and 3 pm daily, using Haar-Synt Hygrometer made in Germany. The averages of temperature and humidity during the experiment were $26.94^{\circ} \mathrm{C}$ and $78.83 \%$, respectively.

\section{RESULTS AND DISCUSSION}

\section{Diets Chemical Composition}

The average of crude protein (Table 1) of all diets was $15.00 \pm 0.46 \%$; these diets were moderately higher than that of required for dairy goat, 12\% (NRC, 1981). The DM in diets provided around $5.07 \%$ of body weight. This was higher than it is supposedly for DM required for $30 \mathrm{~kg}$ dairy goat and $1 \mathrm{~kg}$ of milk production. The PDY and PDM diets similarly contained higher ether extract than others, as the result of incorporation of fatty sources in all diet. These contents were even much higher (average of $8.04 \%$ ) compared to that of $20 \%$ extruded soybean diet $(5.19 \%)$ for lactating goat (Schmidely et al., 2005).

Results in this research confirmed that the fatty sources (roasted corn grain, roasted soybean meal, and corn oil) did increase fat content of the diets. This finding could be a beneficial effect to dairy goat with high concentrate so that it will improve low fat milk that used to be with this level of concentrate. The $5 \mathrm{~g}$ yeast diet (PDY) contained more than twice higher in NDF and $\mathrm{ADF}$ than that of diet with $50 \mathrm{~g}$ Rumisacc, according to Yalçın et al. (2011). Saccharomyces cereviseae populations in diets with yeast (PDY) and mix diet (PDM) were higher than other diets; however, curcuma in the mix diet affected the population by lowering it.

Curcumin and tannin in these diets were decreasing in the average of 16.25 and $27.33 \%$, respectively, compared to their initial source $(0.8 \%$ curcumin and $1.58 \%$ tannin) in $C$. xanthorrhiza Roxb powder. The curcuma diet (PDC) showed the lowest ether extract, suggesting that curcumin blocked this nutrient which is preferred for healthy reason. Tannin contents in all diets were much lower (13.3\%) out 
of $3.69 \%$ found in polyherbal supplements fed to cross bred dairy goat (Mirzaei and Prasad, 2011).

Ratio of $\mathrm{Ca}$ to $\mathrm{P}$ in all diets were above 1.2 : 1 as required for dairy goat according to NRC (1981). The PDY and PDM showed higher ratios of 2.26 and 2.90, respectively. This might be as the effect of yeast fermenting these diets in such a way that $\mathrm{Ca}$ within these diets became more available; then when combined with curcuma, it provided more available $\mathrm{Ca}$, supposedly.

\section{Fatty Acid Profile of PUFA-Diets}

Noticeable fatty acids (Table 2), such as in PD0-A was found three times higher than others in stearate (C18:0), 13 times smaller in $\mathrm{P} / \mathrm{S}$ ratio, eight times smaller than that of PDM in oleate (C18:1n9t), three times smaller than that of PDM in MCFA, 16 times smaller than that of PDM in PUFA, but 2.3 times higher in $n 6 / n 3$ ratio than those of the three other diets. As of PDM, there were some marked higher results, such as in oleate (C18:1n9t), linoleate (C18:2n6c), linolenate (C18: 3n3), EPA, total fatty acid, total MCFA, and total PUFA. On the other hand, PDY was high in total LCFA, total MUFA, and total SFA; while PDC was high in total unsaturated and U/S ratio, but low in atherogeneicity index.

The three treated PUFA- diets (PDM, PDC, and PDY) were similarly had higher $\mathrm{P} / \mathrm{S}$ and lower $n 6 / n 3$ than that of PD0-A. These P/S ratios were lower than the previous PUFA-concentrate containing palm oil and roasted ground corn (2.99-3.07) and the $n 6 / n 3$ ratios were much higher in this present data, compared to 1.5-1.74) reported by Sulistyowati et al. (2010). These present data were within the range of 0.88-1.69 in concentrate with saturated hydrogenated fat and unsaturated ca-soap fat, respectively as reported by Harvatine and Allen (2006). These suggested that the type of fat incorporated in concentrate would determine the type of fatty acid yielded.

Based on these fatty acid quality, it seemed that PUFA-diet with a mixture of $5 \mathrm{~g}$ yeast and 20 $\mathrm{g}$ curcuma powder (PDM) is considered the most effective diet then followed by PDC and PDY. Suggesting that yeast additive worked in fermenting nutrients, at the same time the curcuma controlled the fatty acid contents in diets containing PUFA.

\section{Fatty Acid Profiles of Milk}

Total milk SCFA (C10 and C8) was low in PDC; while the MCFA (C11, C12, and C13) was markedly highest $(\mathrm{P}<0.05)$ in milk of dairy goat fed PUFA-diet with no additive (PD0), displayed in Table 3. Oleic acid (C18:1n9c) $(19.66 \pm 2.89 \%)$

Table 2. Total Fatty Acid contents in PUFA-diets Supplemented with Asifit, Yeast and C. xanthorrhiza Roxb for Dairy Goat

\begin{tabular}{lrrrr}
\hline \multicolumn{1}{c}{ Fatty acid (w/w, \%) } & PD0-A & PDY & PDC & PDM \\
\hline Total fatty acid & 19.17 & 48.02 & 37.74 & 54.16 \\
Total SCFA & nd & nd & nd & 0.01 \\
Total MCFA & 4.83 & 11.36 & 9.30 & 13.18 \\
Total LCFA & 13.83 & 47.37 & 28.32 & 40.7 \\
Total MUFA & 2.61 & 26.68 & 11.88 & 17.59 \\
Total PUFA (P) & 1.06 & 15.82 & 12.83 & 17.59 \\
Total Saturated fat (S) & 15.39 & 16.31 & 12.97 & 18.82 \\
Total Unsaturated (U) & 84.61 & 83.69 & 87.03 & 81.18 \\
Rasio P/S & 0.07 & 0.97 & 0.99 & 0.93 \\
Rasio U/S & 5.50 & 5.13 & 6.71 & 4.31 \\
n6/n3 & 13.14 & 5.83 & 5.57 & 5.86 \\
Atherogenicity & 1.44 & 1.06 & 0.87 & 1.23 \\
\hline
\end{tabular}

PD0-A:PUFA- diet with no suppl. (the PDA, with Asifit was not added to the PD-diet, given orally); PDY: PUFA-diet with $5 \mathrm{~g}$ yeast; PDC: PUFA- diet with $20 \mathrm{~g}$ curcuma; PDM: PUFA- diet with $5 \mathrm{~g}$ yeast $+20 \mathrm{~g}$ curcuma. 
Table 3. Fatty Acid Contents in Milk of Dairy Goat fed PUFA-diet Supplemented with Asifit, Yeast and C. xanthorrhiza Roxb

\begin{tabular}{|c|c|c|c|c|c|c|c|}
\hline Variables & PD0 & PDA & PDY & PDC & PDM & SEM & $\mathrm{P}$ \\
\hline Dry matter intake $(\mathrm{g} / \mathrm{d})$ & 1228.9 & 1128.9 & 1273.1 & 1153.9 & 1239.9 & 60.88 & NS \\
\hline Milk yield (g/d) & 105 & 572 & 526 & 90 & 324 & 226 & $*$ \\
\hline Fat $(\%)$ & 4.83 & 5.96 & 5.19 & 4.54 & 4.35 & 0.64 & NS \\
\hline \multicolumn{8}{|l|}{ Fatty acid (w/w, \%) } \\
\hline Caproic acid, C6:0 & $1.94^{\mathrm{b}}$ & $1.69^{\mathrm{ab}}$ & $1.53^{\mathrm{a}}$ & $1.65^{\mathrm{a}}$ & $1.70^{\mathrm{ab}}$ & 0.15 & $*$ \\
\hline Caprilic acid, C8:0 & 1.57 & 1.425 & 1.44 & 1.44 & 1.33 & 0.08 & NS \\
\hline Capric acid, C10:0 & 4.98 & 4.35 & 4.59 & 5.12 & 4.03 & 0.45 & NS \\
\hline Undecanoic acid, C11:0 & $0.07^{\mathrm{b}}$ & $0.04^{\mathrm{a}}$ & $0.05^{\mathrm{a}}$ & $0.06^{\mathrm{ab}}$ & $0.05^{\mathrm{a}}$ & 0.01 & $*$ \\
\hline Lauric Acid, C12:0 & $2.29^{\mathrm{bc}}$ & $1.69^{\mathrm{ab}}$ & $1.6^{\mathrm{ab}}$ & $2.25^{\mathrm{c}}$ & $1.52^{\mathrm{a}}$ & 0.37 & $* *$ \\
\hline Tridecanoic Acid, C13:0 & $0.07^{\mathrm{b}}$ & $0.05^{\mathrm{a}}$ & $0.05^{\mathrm{a}}$ & $0.06^{\mathrm{ab}}$ & $0.05^{\mathrm{a}}$ & 0.01 & $*$ \\
\hline Myristic Acid, C14:0 & 5.69 & 4.54 & 4.48 & 5.78 & 4.66 & 0.64 & NS \\
\hline Myristoleic Acid, C14:1 & 0.14 & 0.09 & 0.07 & 0.15 & 0.08 & 0.04 & NS \\
\hline Pentadecanoic Acid, C15:0 & 0.63 & 0.51 & 0.505 & 0.625 & 0.58 & 0.06 & NS \\
\hline Palmitic Acid, C16:0 & 19.09 & 15.75 & 16.13 & 19.87 & 18.26 & 1.81 & NS \\
\hline Palmitoleic Acid, C16:1 & 1.00 & 0.87 & 0.675 & 1.035 & 0.96 & 0.14 & NS \\
\hline Heptadecanoic Acid, C17:0 & 0.45 & 0.475 & 0.37 & 0.45 & 0.49 & 0.05 & NS \\
\hline Stearic Acid, C18:0 & 8.97 & 9.96 & 10.20 & 9.67 & 12.58 & 1.37 & NS \\
\hline Oleic Acid, C18:1n9c & 17.38 & 21.66 & 16.21 & 19.89 & 23.15 & 2.89 & NS \\
\hline Linoleic Acid, C18:2n6c & 1.85 & 2.81 & 1.92 & 3.03 & 2.34 & 0.52 & NS \\
\hline Arachidic Acid, C20:0 & 0.19 & 0.155 & 0.18 & 0.195 & 0.20 & 0.02 & NS \\
\hline Cis-11-Eicosenoic Acid, C20:1 & $0.04^{\mathrm{b}}$ & $0.03^{\mathrm{a}}$ & $0.025^{\mathrm{a}}$ & $0.04^{\mathrm{b}}$ & $0.03^{\mathrm{a}}$ & 0.01 & $*$ \\
\hline Linolenic Acid, C18:3n3 & 0.14 & 0.25 & 0.18 & 0.31 & 0.20 & 0.06 & NS \\
\hline Heneicosanoic Acid, C21:0 & 0.09 & 0.05 & 0.07 & 0.14 & 0.05 & 0.04 & NS \\
\hline Cis-11,14-, EDA, C20:2 & 0.06 & 0.06 & 0.05 & 0.06 & 0.05 & 0.01 & NS \\
\hline Behenic Acid, C22:0 & 0.07 & 0.04 & 0.06 & 0.07 & 0.06 & 0.01 & NS \\
\hline Arachidonic Acid, C20:4n6 & 0.14 & 0.13 & 0.09 & 0.14 & 0.08 & 0.03 & NS \\
\hline Tricosanoic Acid, C23:0 & 0.04 & nd & nd & 0.02 & 0.02 & 0.01 & - \\
\hline Lignoceric Acid, C24:0 & 0.03 & 0.02 & 0.02 & 0.03 & 0.02 & 0.01 & NS \\
\hline Cis-5,8,11,14,17-EPA, C20:5n3 & nd & 0.03 & nd & 0.02 & nd & 0.01 & - \\
\hline Total Fatty Acid & 66.81 & 66.67 & 60.5 & 72.03 & 70.61 & 4.48 & NS \\
\hline Total SCFA (C4- C10) & 8.49 & 7.97 & 7.75 & 9.36 & 7.07 & 0.86 & NS \\
\hline Total MCFA (C12- C16) & 28.99 & 25.97 & 25.78 & 30.95 & 26.15 & 2.30 & NS \\
\hline Total LCFA $(\mathrm{C}>\mathrm{C} 16)$ & 29.27 & 35.17 & 32.54 & 31.04 & 39.21 & 3.88 & NS \\
\hline Total MUFA & 18.81 & 22.42 & 18.91 & 19.23 & 24.55 & 2.58 & NS \\
\hline Total PUFA (P) & 1.99 & 2.82 & 2.27 & 3.86 & 2.54 & 0.72 & NS \\
\hline Total Saturated fatty acid (SFA) & 62.06 & 63.83 & 61.53 & 65.11 & 67.42 & 2.39 & NS \\
\hline Total Unsat. fatty acid (UFA) & 37.94 & 36.17 & 38.47 & 34.89 & 32.58 & 2.39 & NS \\
\hline P/SFA & 0.03 & 0.05 & 0.04 & 0.06 & 0.04 & 0.01 & NS \\
\hline UFA/SFA & 0.61 & 0.59 & 0.66 & 0.54 & 0.49 & 0.07 & NS \\
\hline n6/n3 & 23.53 & 10.74 & 11.55 & 11.17 & 12.84 & 5.40 & NS \\
\hline Atherogeneicity & 3.40 & 2.90 & 2.82 & 3.89 & 2.67 & 0.50 & NS \\
\hline
\end{tabular}

PD0:PUFA- diet with no suppl.; PDY: PUFA- diet with 5g yeast; PDC: PUFA- diet with $20 \mathrm{~g}$ curcuma; PDM: PUFA- diet with $5 \mathrm{~g}$ yeast $+20 \mathrm{~g}$ curcuma. * Significant effect $(\mathrm{P}<0.05)$. ** Very significant effect $(\mathrm{P}<0.01)$. NS: not significant. 
and palmitic acid (C16) (17.82 $\pm 1.81 \%)$ dominated out of total fatty acid in both curcuma diets (PDC and PDM). Stearic acid (C18:0) and oleic acid $(\mathrm{C} 18: \ln 9 \mathrm{c})$ numerically increased in PDM; while linoleic acid (C18:2n6c) and linolenic acid (C18:3n3) was found the highest in PDY. This was about the same as with $2.5 \%$ soybean oil, in which C18:2 was higher, followed by $\mathrm{C} 18: 1$; while $\mathrm{C} 18: 3$ and $\mathrm{C} 18: 0$ decreased in milk of Murciano Granadina goat (Bouattour et al., 2008). Oleic acid was a result of synthesis process involving enzim $\Delta^{9}$ desaturase on C18:0 (Stearic acid) in mammary gland, by which stearic acid was having positive correlation with milk fat content in goat (Chilliard et al., 2006). In yeast and curcuma diet (PDM), C18:0 was found the highest while its milk fat was the lowest.

Roasting of soybean meal and ground corn is an effort to improve the contents of fatty acid, especially PUFA. Roasted soybean yielded higher fatty acid of C18:1, C18:2, and C18:3 (Chouinard et al., 2001). It happened in the high contents of oleic acid (C18:1n9c), linoleic acid (C18:2n6c), and linolenic acid $(\mathrm{C} 18: 3 \mathrm{n} 3)$. Heating process made the oil is ready later after by passing rumen biohydrogenation.

Most of fatty acid was synthesized in mammary gland (mammary de novo) in the forms of saturated fatty acid (SFA) and C10- C16, while LCFA strongly disturbed de novo synthesis (Chilliard et al., 2003). This effect will work stronger when the LCFA was more unsaturated. However, this fatty acid was only about $45 \%$ coming from SFA in these five treatments. Meanwhile, biohydrogenation process of fatty acid into intermediates was affected by type of fatty acid being supplemented in diet.

Other result showed that Ca-flaxseed supplementation produced highest LCFA and PUFA; while SFA, SCFA, and MCFA were the lowest (Cortes et al., 2010). Supplementation of XP yeast yields total fatty acid in milk with $\mathrm{C}<16$, $\mathrm{C} 16$, and $\mathrm{C}>16$, as high as, 26.1, 25.2, and 17.4 $\mathrm{g} / 100 \mathrm{~g}$ fatty acids, respectively, which were not different from control diet in milk (Hristov et al., 2010). These fatty acid sources and yeast additive both affected lipid metabolism in rumen and fatty acid synthesis in mammary gland that eventually would determine the fat and fatty acid composition in milk. Combined with curcuma in diet with these supplements, it will further affect the fatty acid composition in milk of dairy goats in this present experiment.

Ratio of UFA/SFA in PDC (0.49) and PDY

Table 4. Fatty Acid Contents in Feces of Dairy Goat Fed PUFA-Diet Supplemented with Asifit, Yeast and C. xanthorrhiza Roxb

\begin{tabular}{lrrrrr}
\hline Variable & PD0 & PDA & PDY & PDC & PDM \\
\hline Fat $(\%)$ & 2.05 & 2.15 & 2.04 & 2.47 & 2.06 \\
Total fatty acid & 27.33 & 24.94 & 24.52 & 36.32 & 36.04 \\
Total Short CFA (C4-C10) & $\mathrm{nd}$ & $\mathrm{nd}$ & $\mathrm{nd}$ & $\mathrm{nd}$ & $\mathrm{nd}$ \\
Total MCFA (C12- C16) & 6.11 & 6.39 & 6.92 & 9.06 & 8.62 \\
Total LCFA (C>C16) & 48.54 & 43.46 & 42.11 & 63.13 & 63.14 \\
Total MUFA & 0.64 & 0.65 & 0.71 & 0.74 & 0.16 \\
Total PUFA(P) & 1.76 & 1.51 & 1.46 & 2.16 & 12.22 \\
Total Saturated fatty acid(SFA) & 21.34 & 19.75 & 19.48 & 28.92 & 11.86 \\
Total Unsaturated fatty acid (UFA) & 78.66 & 80.25 & 80.52 & 71.08 & 88.14 \\
Rasio P/SFA & 0.08 & 0.08 & 0.07 & 0.07 & 1.03 \\
Rasio UFA/SFA & 3.69 & 4.06 & 4.13 & 2.46 & 7.43 \\
n6/n3 & 10.60 & 10.46 & 11.00 & 8.30 & 5.82 \\
\hline
\end{tabular}

PD0:PUFA- diet with no suppl.; PDA: PUFA- diet with Asifit tablet; PDY: PUFA- diet with 5 g yeast; PDC: PUFA- diet with 20g curcuma; PDM: PUFA-diet with $5 \mathrm{~g}$ yeast $+20 \mathrm{~g}$ curcuma. 
(0.66) were higher than recommended ratio $(0.40 \%)$. Ratios of $n 6 / n 3$ in the milk of goats fed a respective treatment were in the range of 10.7412.84; while, milk of control diet (PD0) was having about twice higher than the milk of the other four treatments. These n6/n3 ratios were even higher than the milk of goat fed $20 \%$ extruded soybean (8.52) and control (5.77) reported by Schmidely et al. (2005). Other researcher (Cortes et al., 2010) showed lower $\mathrm{n} 6 / \mathrm{n} 3$ in milk of dairy cows fed flaxseed, Caflaxseed oil, and their combination were 3.48, 2.61, and 2.19, respectively. Ratio of $n 6 / n 3$ recommended for human health were about 5:1 and 10:1 according to World Health Organization, WHO (Bouattour et al., 2008).

Based on this criteria, ratios of $n 6 / n 3$ in goat milk with treated PUFA- diets in this experiment were slightly higher, whereas the milk of control diet was about doubled of the others. Therefore, supplementations of Asifit tablets, yeast, $C$. xanthorrhiza Roxb or in combination of the last two were able to decrease the ratios of $n 6 / n 3$ for about $50 \%$ so that they were closer to that standard.

Atherogeneicity index in PDC was the lowest in milk of goat fed PDC (2.67) and the highest was in milk with PDY (3.87). These indexes were about in the same range of milk with goat fed soy bean oil (2.20), lower than control, 3.29 (Bouattour et al., 2008) and 3.48 in goat milk with $20 \%$ extruded soybean (Schmidely et al., 2005). Atherogenic diet added with medium $(0.3 \%)$ and high $C$. xanthorrhiza Roxb (0.4\%), significantly lowered peroxidation of LDL, 1.636 and $1.572 \%$, respectively, compared to control $(4.684 \%)$ in 4 months old rabbit (Wientarsih and Muelen, 2008). This index is an indicator of SFA that might cause cardiovascular disorder. However, Chilliard et al., (2006) concluded based on several studies that there was very few of the evidences between MCFA and SFA causing that disorder compared to diet with low fat but high fat and carbohydrate consumptions.

\section{Fatty Acid Profiles of Feces}

Fatty acid levels in feces were found to have some consistent tendencies (Table 4). Curcuma supplementation both in PDC and PDM were higher in MCFA and LCFA than other treatments. In PDM, there were numerically found to be lower in MUFA, SFA, and n6/n3. In contrast, this diet was higher in PUFA, UFA, PUFA/SFA, and UFA/SFA. Meanwhile, atherogenicity index was found to be high both in PDC and PDM; suggesting that curcuma supplementation either singly or in combination with yeast would stimulate bile production such that it will digest more lipid and excreted later in the feces. As the results, the indexes of both feces were high. In terms of the index in milk, it is consequently would be low (2.67 in PDM), which is better for health consciousness.

\section{CONCLUSIONS}

Diet containing polyunsaturated fatty acid (PUFA) supplemented with $5 \mathrm{~g}$ yeast and $20 \mathrm{~g}$ curcuma (C. xanthorrhiza Roxb) were high in total fatty acid, MCFA, LCFA, and PUFA. Milk fatty acid quality of goat fed with this diet showed high in LCFA and MUFA; while it was low in SCFA, unsaturated fatty acid, n6/n3 ratio, and atherogenicity index. These qualities were optimally considered good in terms of healthier product. Therefore, the PUFA- diet with $5 \mathrm{~g}$ yeast and $20 \mathrm{~g}$ curcuma was considered as a reasonable choice to be applied for dairy goat.

\section{ACKNOWLEDGEMENTS}

Authors would like to thank Directorate General for Higher Education (DGHE) for funding this project through HIBAH STRANAS IPB with contract no:134/SP2H/PL/ DIT.LITABMAS/V/2013, signed on May 13, 2013. Appreciations were also extended to Ir. Sigit Mujiharjo, MSAE for checking with statistical analysis; Cordero farm owner, workers, and students for helping in the farm; and coworkers for laboratory .

\section{REFERENCES}

Bouattour, M.A., R. Casals, E. Albanell, X. Such, and G. Caja. 2008. Feeding soybean oil to dairy goats increases conjugated linoleic acid in milk. J. Dairy Sci. 91:2399-2407.

Chilliard, Y., A. Ferlay, J. Rouel, and G. Lamberet. 2003. A Review of Nutritional and Physiological Factors Affecting Goat Milk Lipid Synthesis and Lipolysis. J. Dairy Sci. 86:1751-1770.

Chilliard Y., J. Rouel, A. Ferlay, L. Bernard, P. Gaborit, K. Raynal-Ljutovac, A.Lauret, and C. Leroux. 2006. Optimising goat milk and cheese fatty acid composition. In: 
Improving the Fat Content of Foods. C. Williams and J. Buttriss, ed. Woodhead Publishing Limited, Cambridge, UK. P. 281- 282.

Chuinard, P. Y., L. Crneau, W. Butler, Y. Chilliard, J. K. Drackley, and D. E. Bauman. 2001. Effect of dietary lipid source on conjugated linoleic acid concentrations on milk fat. J.Dairy Sci. 84: 680-690.

Cortes C., D.C. daSilva-Kazama, R. Kazama, N. Gagnon, C. Benchaar, G.T.D. Santos, L.M. Zeoula, and H.V. Petit. 2010. Milk composition, milk fatty acid profile, digestion, and ruminal fermentation in dairy cows fed whole flaxseed and calcium salts of flaxseed oil. J Dairy Sci. 93:3146- 3157.

Harvatine, K.J. and M.S. Allen. 2006. Effects of fatty acid supplements on milk yield and energy balance of lactating dairy cows. J. Dairy Sci. 89:1081-1091.

Hristov, A.N., G. Varga, T. Cassidy, M. Long, K. Heyler, S.K.R. Karnati, B. Corl, C.J. Hovde, and I.Yoon. 2010. Effect of Saccharomyces cerevisiae fermentation product on ruminal fermentation and nutrient utilization in dairy cows. J. Dairy Sci. 93 :682-692.

Jayaprakasha, G.K, L.J.M. Rao, and K.K. Sakariah. 2002. Improved HPLC Method for the determination of curcumin, demethoxycurcumin, and bisdemethoxycurcumin. J. Agric. Food. Chem. 50: 36683672.

Lentner, M. and T. Bishop.1986. Experimental Design and Analysis. Valley Book Co. VA.

Mirzaei, F. and S. Prasad. 2011. Influence of dietary phytoadditive as polyherbal combination on performance of does and respective litters in cross bred dairy goats. Asian-Aust. J. Anim. Sci. 24(10):1386-1392

National Research Council (NRC). 1981. National Research Council. Nutrient Requirements of Goats: Angora, Dairy, and Meat Goats in Temperate and Tropical Countries. National Academy Press. Washington, DC (US).

Petit, H.V. 2003. Digestion, milk production, milk composition, and composition of dairy cows fed formaldehyde treated flaxseed or sunflower seed. J. Dairy Sci. 86:2637- 2646.

Pusbangtepa. 1981. Ragi Tape. Buletin Pusbangtepa. Pusat Penelitian dan Pengembangan Teknologi Pangan. IPB. Bogor. Indonesia.

Rukayadi, Y., J.S. Shim andJ.K. Hwang. 2008. In vitro antistaphyolococcal activity of xanthorrhizol isolated from the rhizome of temulawak (Curcuma xanthorrhiza Roxb). Proceedings of the First International Symposium on Temulawak. IICC. Bogor, Indonesia. May 27- 29. Pp: 57- 70.

Schmidely, P., P. Morand- Fehr, and D. Sauvant. 2005. Influence of extruded soybeans with or without bicarbonate on milk performance and fatty acid composition on goat milk. J. Dairy Sci. 88: 757- 765.

Sinaga, S., D.T.H. Sihombing, M. Bintang, and Kartiarso. 2011. The effect of ration containing curcumin (extract turmeric/ Curcuma domestica) in pigs rations to replace antibiotic synthetic as growth promoter). Forum Pascasarjana. 33(2):123131.

Sulistyowati, E., S.A. Abutani, and Mujiharjo. 2001. Produksi Susu Sapi Potong Laktasi dengan Teknologi Tabut. Media Peternakan. 24 (2):51-53.

Sulistyowati , E., U. Santoso, and I. Badarina. 2010. Milk production and modification of milk fatty acid of dairy cows fed PUFAconcentrate. J. Indonesian Trop. Anim. Agric. 35 (4):262-267.

Sutrisno, D. Sukarianingsih, M. Saiful, A. Putrika, and D.I. Kusumaningtyas. 2008. Curcuminoids from Curcuma xanthorrhiza Roxb: isolation, characterization, identification. Proceedings of the First International Symposium on Temulawak. IICC. Bogor (ID). May 27-29. Pp: 225- 230.

Ulbricht, T.L.V. and D.A.T. Southgate. 1991. Coronary heart disease: Seven dietary factors. Lancet. 338:985-992

Whitlock, L.A., D.J. Schingoethe, A.R. Hippen, K.F. Kalscheur, R.J. Baer, N. Ramasmy, and K.M. Kasperson. 2002. Fish oil and extruded soybeans fed in combination increase conjugated linoleic acids in milk of dairy cows more than fed separately. J Dairy Sci. 85: 234-243.

Wientarsih, I. and U. Meulen. 2008. The effect of diets varying in curcuma (Curcuma xanthorrhiza Roxb) on blood plasma LDLperoxidation in rabbits. Proceedings of the First International Symposium on Temulawak. IICC. Bogor (ID). May 27-29. Pp: 313-316.

Yalçın, S., C. Pınar, O. Arif, Gürdal, C. Bağc, and O. Eltan. 2011. The nutritive value of live yeast culture (Saccharomyces cerevisiae) and its effect on milk yield, milk 
composition and some blood parameters of dairy cows. Asian- Aust J. Anim. Sci. 24 (10): 1377-1385.

Zhong, R., W. Xiao, G. Ren, D. Zhou, C. Tan, Z. Tan, X. Han, S. Tang, C. Zhou and M.Wang.
2011. Dietary tea catechin inclusion changes plasma biochemical parameters, hormone concentrations and glutathione redox status in goats. Asian-Aust. J. Anim. Sci. 24(12):1681 - 1689 